\title{
17. The rule of law and judicial independence amidst the coups and attempted coups in Fiji since 1987
}

\section{Tupou Draunidalo}

The purported 'coup' or rebellion' ${ }^{1}$ of 5 December 2006 had a major impact on the Fiji judiciary, and the rule of law. But it did not come out of the blue. The judicial schisms that were exposed in early 2007 followed a pattern established much earlier, in the wake of the 1987 and 2000 coups. This chapter examines those earlier events, showing how they shaped the legal fraternity in Fiji and set the stage for the late 2006 crisis.

When Lieutenant Colonel Sitiveni Ligamamada Rabuka and the Fiji Military Forces entered the parliament of Fiji with arms on 14 May 1987 to remove from office the recently elected prime minister and cabinet, the rule of law in Fiji faced its biggest challenge since Fiji was ceded to Britain in 1874. A High Court judge who heard the news of the coup while he was hearing a case is reported to have adjourned his court immediately and, upon rising to his feet, told the court 'God Save the Queen'. It is fair to surmise that the judge's words were metaphorical for 'God save the rule of law' or 'God save the common law' - that which was transported to Fiji from England by the Queen's men in 1874.

Twenty years, one coup and three attempted coups later the judge's lament could not be more fitting. After May 1987 the deposed prime minister and his colleagues filed proceedings in the High Court of Fiji, challenging their removal from office. Before the High Court could rule on the legality of the removal, Rabuka removed the Governor General and abrogated the 1970 constitution. Some judges resigned from the High Court; some magistrates from the magistracy. They resigned as they felt they could no longer hold appointments in a situation where the supreme law of the land was being assaulted by armed revolutionaries. After this exodus of judges and magistrates, the new regime appointed replacements.

Members of the Fiji Law Society (FLS) were vocal in their opposition to the coup. Some refused to socialize or work in courts presided over by judges appointed by the regime. A number were harassed and imprisoned for their efforts. With the passage of time and firm control of the government by the military, a new, 1990, constitution was promulgated by the first President of the new republic.

A general election was held in 1992 and the coalition parties that had been deposed from power in 1987 contested under the new, raced-based constitution. 
Rabuka (now Brigadier General) led the indigenous-based political party, Soqosoqo ni Vakatulewa ni Taukei (SVT), to victory. To many, it appeared as though the revolution that had begun on 14 May 1987 had been successful. The two legal prerequisites of 'effective control' and, 'acquiescence' appeared to have been met, and the legitimacy of the new order had been sealed by the general election.

In 1997, the parliamentary leaders of the two main communities in Fiji, then prime minister Rabuka and Jai Ram Reddy, after many months of negotiations, brokered a new multiracial constitution; it was unanimously passed by parliament as the supreme law of the land. It was a historic occasion - full of hope and optimism. Unfortunately, the 1997 constitution received a baptism of fire in the events leading up to, during and after the 1999 general election. Both Rabuka and Reddy suffered a heavy defeat at the polls. Fiji Labour Party (FLP) leader Mahendra Chaudhry emerged triumphant and became prime minister. But Chaudhry has never shown the necessary understanding of the indigenous psyche to evade political trouble; and deputy PM Adi Kuini Vuikaba Speed, the leader of the Fijian Association Party - the largest indigenous parliamentary party following the 1999 polls - was enduring persistent health problems and internal party dissension over her moderate politics. On 19 May 2000, George Speight (with the assistance of seven members of a specially trained unit within the Republic of Fiji Military Forces (RFMF)) entered the House of Representatives and held government members hostage for fifty six days.

That event opened an ugly phase in Fiji's political history. After the hostages were released and Speight and his supporters arrested, the new order (and, by association, the legitimation of the removal of the elected government) was consolidated in law by:

- the President of Fiji, Ratu Iloilo, who scheduled early elections for August 2001;

- the commander of the RFMF, Commodore Bainimarama, who swore on an affidavit that he could not guarantee national security if the People's Coalition government was returned to power; and

- Mahendra Chaudhry, who told the President he wanted to go to the polls rather than risk a vote of no confidence in a recalled House of Representatives.

Days after Speight had attempted to overthrow the elected government and the 1997 constitution, a judge of the High Court, Ratu Joni Madraiwiwi, and two magistrates resigned - amidst allegations that the Chief Justice and two other judges of the High Court had drafted decrees to replace the 1997 constitution to assist Commodore Bainimarama and to 'save the state' from the hostage-takers inside parliament. The allegations were made by two other judges of the High Court, Justices Nazhat Shameem and Anthony Gates, and supported by the FLS led by its president, Mr Chen Bunn Young. The FLS and the accused judges exchanged heated correspondence. Some members of the FLS were banned from 
appearing before the judges who had allegedly assisted in drafting the military's post-coup decrees.

For their part, the judges against whom the allegations were made strenuously and consistently denied the allegations. No official complaint was ever made to the Judicial Services Commission. No tribunal was convened or evidence tendered to support the allegations. On the contrary, the Judicial Services Commission under the 1997 constitution and after the 2001 general election - appointed one of the accused judges (Mr Justice Fatiaki, as he then was) to succeed the retiring Chief Justice.

The details of the fraught relationship between some judges of the High Court since May 2000 are part of the public record. In Citizens Constitutional Forum $v$ President [2001] FJHC 28 ('CCF Case'), His Lordship Mr Justice Fatiaki opened his ruling on an application that he remove himself from the matter for apprehended bias by saying:

It is my unpleasant duty to rule on this interlocutory application by the applicants seeking my disqualification from further hearing this matter on the ground of bias. I say unpleasant advisedly firstly because of the very nature of the application which places me in somewhat of an invidious position; and secondly, because of the unprecedented spectacle of me being confronted with the affidavits of two (2) serving colleagues on the bench.

In this Notice of Motion filed on 30.4.2001 counsel for the applicants seeks an order or declaration that I am 'automatically disqualified from hearing or adjudicating upon the matters raised in the applicant's Originating Summons' alternatively, that '... in all the circumstances of the case ... I disqualify myself ...'

The grounds advanced in the Motion are as follows:

(1) that I have 'common cause' with H.E. the current President in the issues raised by the applicants such as to automatically disqualify me from continuing any further with this case;

(2) that I have 'effectively prejudged the same or closely related issues' as those raised in the applicant's substantive Originating Summons such that 'any reasonable bystander would entertain a well-founded apprehension of possible bias on my part';

(3) that the first applicant the CCF has called on H.E. the President to institute an inquiry into my conduct with a view to my removal from office' and this is reason enough for the CCF to apprehend possible bias on my part in determining the case; 
(4) that 'in light of all the facts and circumstances' deposed in the affidavits filed in support of this Motion I should disqualify myself 'in order to maintain public confidence and that of the applicant's in the eventual decision on the substantive application'.

In my view grounds (3) \& (4) as framed, are not proper grounds for the application, rather, both refer to specific and general evidential matters placed before me to consider in my ruling on grounds (1) \& (2). Be that as it may counsel candidly admitted that ground (4) was a 'catch-all' ground. It was not addressed in any meaningful way and I do not propose to deal separately with it in this ruling. ${ }^{2}$

Amongst the affidavits urging the Chief Justice to remove himself were two from High Court judges John Edward Byrne and Nazhat Shameem. Despite his criticism of the litigation, Justice Fatiaki did recommend the appointment of another judge:

... consonant with what might be considered an excess of caution on my part, and mindful of the applicants deposed belief (however misguided) that I might unconsciously succumb to the human temptation to exact revenge for their calls for an enquiry with a view to my removal, I have decided to take the exceptional step of referring the file back to the Chief Justice for reassignment to another judge for the hearing of the substantive Originating Summons as he sees fit. ${ }^{3}$

Another case, four years later, also indicates the bitter schisms that became hallmarks of Fiji's judiciary in the wake of the 2000 coup. In 2005, Justice Nazhat Shameem applied to the Supreme Court to intervene in an appeal brought by Ratu Rakuita Vakalalabure. Ratu Rakuita had been found guilty by assessors of treason-related offences stemming from the 2000 coup. Justice Shameem had sentenced Ratu Rakuita. Ratu Rakuita appealed. One of the three judges scheduled to preside in the appeal case, Justice French, fell ill shortly before the case was heard and Chief Justice Fatiaki appointed Mr Justice Scott in his place. At this juncture Justice Shameem applied to intervene in the hope that Justice Scott might be replaced. The Supreme Court summarized its ruling as follows:

The Supreme Court today published its reasons for refusing the application of Madam Justice Shameem to intervene in the pending proceedings of Ratu Rakuita Vakalalabure $\mathrm{v}$ The State ...Shameem J argued that the level of hostility between Scott JA and herself was such that Scott JA would be biased in determining the appeal, which challenged on legal grounds the conviction and sentence she had handed down at the trial ... A differently constituted Supreme Court has ruled that Shameem $\mathrm{J}$ does not have any right to intervene in the Supreme 
Court proceedings; and that it is inappropriate for leave to be given to her for that purpose. ${ }^{4}$

The ruling detailed the animosity prevailing between the two judges:

On behalf of the applicant [Shameem], it was submitted that Scott JA was automatically disqualified from sitting on the appeal from Shameem $\mathrm{J}$ because of his "past and ongoing implacable hostility and animosity" towards her. That submission was supported by reference to one matter, in particular, that emerged from the affidavit sworn by Shameem $\mathrm{J}$ on 19 October 2005. It concerned a letter dated 29 January 2003 written by Scott JA to the Chief Justice in which he advised that he would not be attending a judges' retreat scheduled for February 2003. He explained that the events of May 2000, and subsequent months, had resulted in a very serious split in the judiciary. He said that in his opinion three judges, Byrne, Shameem and Gates JJ "were guilty of grave misconduct" which resulted in the judiciary in general, and himself in particular, having been brought into disrepute. He said that as a result he had had no social dealings for the past two years with the three judges. ${ }^{5}$

A third indication of the way frictions among senior judges influenced critical court cases in the wake of the 2000 coup is given in Ratu Inoke Takiveikata $v$ The State. ${ }^{6}$ The appellant was a traditional high chief of a large province in Fiji (Naitasiri) and he was tried in the High Court, with Justice Gates presiding, for inciting mutiny in November 2000, an event linked to the coup earlier in that year. The assessors found the accused guilty on a number of counts and not guilty on other counts. Mr Justice Gates overruled the assessors and convicted the accused on all counts and sentenced him to life imprisonment. In the wake of that conviction, Mr and Mrs Brodie approached the lawyers of the accused to advise that, at the beginning of the trial of the accused, the couple had met Mr Justice Gates at a cocktail function and, in the course of exchanging pleasantries, the judge had told the couple that he would 'put [the accused] away'. The lawyers filed their appeal papers, narrowing in on the 'bias' or pre-judgment of the accused by Mr Justice Gates. The Brodies and the judge deposed affidavits for the appeal and they were all examined and cross-examined. By the time the Court of Appeal sat to deliberate on this case, the military had executed its 2006 coup, Chief Justice Fatiaki had been suspended, and Justice Gates had been elevated to Chief Justice (in a manner described below). Judges on the Court of Appeal declared their intention to resign, unwilling as they were to serve under a military-installed Chief Justice. However, before departing, in an astonishing ruling, they found that the Brodies' account of what transpired was accurate, and that Gates was biased. They upheld the appeal, ordered a new trial, and provided that Ratu Inoke Takiveikata be released. 
These divisions in the judiciary, born out of the upheavals of 2000, reached their climax in the forced removal of Chief Justice Fatiaki from his chambers on 4 January 2007 following the 5 December 2006 rebellion. Eleven days later, on 15 January 2007, the military-appointed interim Attorney-General purported to convene a meeting of the Judicial Services Commission to appoint an 'acting Chief Justice'. That meeting was chaired by Justice Nazhat Shameem. It appointed Justice Anthony Gates as acting Chief Justice. The then president of the Fiji Law Society attended the purported meeting and was the only constitutional member of the Judicial Services Commission present. The other two constitutional members of the Commission, the chair of the Public Service Commission and the Chief Justice, had both been forcibly removed from office by the military.

In March 2007, the association of lawyers for the Asia Pacific region, LAWASIA, sent an observer mission to Fiji to report on the status of the rule of law and the judiciary after the December 2006 rebellion and the forced removal of the Chief Justice by military personnel. The mission interviewed a cross-section of stakeholders, including the military and civilian usurpers, various judges and lawyers. The mission published its observations and recommendations, which included the comment that, 'members of the legal profession must be entitled to speak openly about all of these issues without the fear of intimidation by the military'.7

Notwithstanding, two lawyers for a statutory body suspended by the military were taken to the army camps for questioning and I, as vice-president of the Fiji Law Society, was committed for contempt proceedings by the usurper Attorney-General Aiyaz Sayed-Khaiyum for discussing notorious facts regarding the state of the judiciary.

In addition, prior to the visit by the LAWASIA mission, a critic of the regime and, the senior partner at the biggest law firm in Fiji, Mr Richard Naidu, was abducted from his home by soldiers (in full view of his wife and young children) and taken to an unknown location where he was assaulted for some hours.

The LAWASIA mission's report also stated, 'the rule of law in Fiji may be compromised by the on-going uncertainty as to the status and future of the suspended Chief Justice Fatiaki and the on-going public perception right or wrong, that the judiciary is politicized and divided'. ${ }^{8}$ Nevertheless, the Chief Justice remained suspended. The Tribunal looking into allegations of misconduct against the Chief Justice was itself adjourned to allow the courts to determine the validity of its own establishment.

There are other signs that the military-backed interim regime has flouted the rule of law and rejected scrutiny by other respected international legal organizations. In February 2008 the International Bar Association arranged to send a mission to Fiji; it was refused entry by the usurpers. The regime has also 
rejected a request from the UN Special Rapporteur on the Independence of Judges and Lawyers for an observer mission to Fiji.

At a dinner hosted by the Council of the Fiji Law Society for the visiting LAWASIA mission, one of the LAWASIA delegates confided that he could not fathom how the judiciary in Fiji managed to operate in the post-2000 atmosphere of animosity and venom. Other delegates agreed, saying that in their combined years of legal practice they had never encountered such dysfunction in their various jurisdictions.

The FLS fought the removal of the Chief Justice and challenged the constitutional validity of the purported meeting of the Judicial Services Commission convened to appoint the new acting Chief Justice. As the then vice-president, I am proud to say that the FLS took action against both decisions, and stood firmly for the rule of law. There were differences of opinion amongst FLS members but the majority maintained their principles despite attack from the military regime. Nevertheless, some, mostly senior, members, refrained from supporting this stance out of caution, fear, opportunism or support for the December 2006 rebellion.

A Judicial Review of the activities of the Judicial Services Commission in the wake of the 2006 coup is, at the time of writing, before the courts, and delays in proceedings have sparked further public feuds between the president of the FLS and the usurper Attorney-General. The opinion of three overseas senior counsels is that the purported meeting was not convened lawfully. The military regime refused to allow the entry into Fiji of the FLS' counsel of choice, Dr John Cameron, a breach of the FLS' constitutional right. Dr Cameron had been a magistrate in Fiji until the September coup of 1987; he has been a long-time resident and been adopted by an indigenous land-owning unit. Earlier, Dr Cameron had conducted many proceedings against the post-1987 coup regime for the benefit of victims of that coup (including the deposed prime minister, Dr Timoci Bavadra, and his colleagues).

In June 2007, the former president of the FLS, Mr Graham Leung, presented the issues currently affecting the rule of law and judiciary in Fiji to the 50th anniversary LAWASIA conference in Hong Kong. He pointed out that what distinguished the 2006 coup from those in 1987 and 2000 'was the extent to which senior members of the Bench and Bar appear to have been complicit, either before the event or subsequently'. Mr Leung also made comment about the Judicial Services Commission's appointment of an acting Chief Justice:

It was at that meeting [purported meeting], that the Judicial Services Commission ['JSC'], as constituted, purported to appoint Mr Justice Anthony Gates as Acting Chief Justice. The fact he had apparently been consulted in advance and that Justice Shameem had obtained an opinion 
justifying her chairing of the JSC indicates a measure of prior knowledge. ${ }^{9}$

As a result of the purported JSC meeting - all expatriate judges of the Court of Appeal and High Court of Fiji either resigned, did not renew their contracts, or terminated their contract. One of those judges, the Honourable Mr Justice Roger Coventry, at the beginning of his farewell speech to members of the Fiji Law Society in December 2007 said:

It is with great sadness that I stand here this evening. If there could be some other course consistent with principle whereby I could to stay then I would take it. I regret there is not. ${ }^{10}$

His Lordship continued:

In the latter part of last year came the resignation of the entire panel of the Court of Appeal. The reasons they gave were clear and understandable. Whilst legally the system may continue, it is an unsatisfactory state of affairs. 11

His Lordship ended by reminding the very many lawyers present at his farewell that 'acquiescence [to usurpers] is the friend of illegality'.

Prior to the resignation of the Court of Appeal panel, the usurper Attorney-General made scathing remarks against the retiring president of the Fiji Court of Appeal, the Honourable Mr Justice Gordon Ward at the 50th anniversary LAWASIA meeting.

Not long after His Lordship refused to renew his contract his private home at Pacific Harbour near the capital Suva was burnt to the ground, investigations into the fire are continuing.

The regime imposed punitive measures on members of the FLS who were vocal dissenters against the military regime and critics of the purported JSC meeting. Very early in their rebellion, the regime announced that it would withdraw all government work from two prominent private law firms (Munro Leys and Howards).

Overseas travel bans were imposed on Graham Leung. Other violations of human rights have been experienced by senior lawyers. Mr Leung has complained about computer hacking and tapped telephones at his law firm.

As vice-president of the FLS, I also had my share of trouble with the authorities, associated with both my work for the society and for clients opposed to the military regime. This included questioning by police on complaints of sedition, a ban on overseas travel and committal proceedings for contempt of court. On 20 November 2007, the court allowed the applicant to withdraw the proceeding. The following passage is extracted from the first paragraph of His Lordship's 
ruling, three weeks later, on the state's application for leave to appeal his judgment and orders:

On $20^{\text {th }}$ November 2007 I gave my 'Ruling Upon Application to Discontinue Action and Costs'. Leave was granted for the applicant to withdraw the proceedings. Assessed indemnity costs in the sum of $\$ 20,000$ (Twenty Thousand Dollars) were awarded against the applicant. In essence I found that that Attorney General had been irresponsible in bringing the proceeding, they were brought for an ulterior purpose and that it was "beyond understanding how the Attorney General could put Ms. Draunidalo at risk of imprisonment and fine for words she uttered when he himself had used far stronger words only a few days earlier" about the President of the Court of Appeal. ${ }^{12}$

In December 2007, the leader of the 2006 rebellion, Commodore Bainimarama, attacked the members of the legal profession while speaking at the annual Attorney-General's conference. He alleged that the profession failed to properly regulate itself, indulged in 'judge-shopping', and had many unethical members. The FLS president rebuffed him.

At present, the Court of Appeal is comprised entirely of persons associated with, or appointed by, the purported Judicial Services Commission.

In October 2007 Mr Justice Davendra Pathik struck out an application by one Angenette Melania Heffernan for Mr Justice Pathik to recuse himself from hearing the substantive matter. In the matter, Ms Heffernan sought the adjudication of her applications by a judge not having any association whatsoever with the purported meeting of the Judicial Services Commission on 15 January 2007. ${ }^{13}$ The respondents in the matter were Messrs Justices Byrne and Gates and, the usurper Attorney-General and, it should be noted that the appointments of Messrs Justices Pathik, Byrne and Gates are all before the High Court of Fiji inter alia the Fiji Law Society Judicial Review questioning the constitutional validity of the purported meeting of the Judicial Services Commission.

In striking out the application for recusal, Mr Justice Pathik ruled that lawyers and the public in general should not question the appointment of judges nor the acts and decisions of persons appointed as judges, as judges enjoy immunity from such proceedings. ${ }^{14}$ The FLS has recently decided to intervene as amicus in the related constitutional redress case, and any appeal from that decision. The rulings in the matter from Messrs Justices Pathik and Hickie ${ }^{15}$ (as single judge of Court of Appeal) speak for themselves.

The constitutional case brought by the deposed government was heard by three adjudicators appointed by the same JSC whose composition is under challenge before the courts. The panel comprises Justice Gates, Byrne and Pathik. At the time of writing, the country awaits the decision of that panel to determine the 
legal status of the December 2006 rebellion, the fate of the government elected in May 2006, and, more broadly, the future of our evolving and fragile democracy. Some of Fiji's lawyers and judges have shown great wisdom and courage during the last twenty years. Others have not. If the challenges ahead are to be met, the legal profession must, in the words of Graham Leung, 'redeem itself and reject the easier path of ambivalence, equivocation, silence and cowardice'. ${ }^{16}$

\section{ENDNOTES}

1 As the perpetrators of the December 2006 events claim that the constitution has not been abrogated, and that it remains intact, I use the term rebellion rather than coup in this paper.

2 Citizens Constitutional Forum v President [2001] FJHC 28

3 Citizens Constitutional Forum v President [2001]

4 Vakalalabure v State [2006] FJSC 3; CAV0003U.2004S (1 May 2006)

5 Vakalalabure $v$ State [2006]

6 Criminal Appeal No AAU065 of 2004.

7 Report of visit to Fiji by LAWASIA Observer Mission, 25-28 March 2007, LAWASIA, Secretariat GPO Box 980 Brisbane Qld Australia 4001.

8 Report of visit to Fiji by LAWASIA Observer Mission, 25-28 March 2007

9 Speech by Mr Graham Leung, Former President of the Fiji Law Society at the 50th Anniversary of LAWASIA, Hong Kong, June, 2007. Reproduced as Chapter 15, this volume.

${ }^{10}$ Written Farewell Speech of His Lordship Mr Justice Roger Coventry at the Tanoa Plaza, December, 2007.

11 Written Farewell Speech of His Lordship Mr Justice Roger Coventry.

12 Miscellaneous Action No. 0053 of 2007, High Court of Fiji at Suva, Civil Jurisdiction

13 Angenette Melania Heffernan v John Edward Byrne \& Ors, Civil Action HBM 105 of 2007; I declare that I have at various intervals appeared for the Applicant Ms. Angenette Heffernan.

14 Angenette Melania Heffernan v John Edward Byrne \& Ors, Civil Action HBM 105 of 2007

15 Angenette Melania Heffernan v John Edward Byrne \& Ors, Civil Appeal ABU 34 of 2007

16 Angenette Melania Heffernan v John Edward Byrne \& Ors, Civil Appeal ABU 34 of 2007, p.9. 